\title{
ЭМОЦИОНАЛЬНО-ОЦЕНОЧНЫЕ ПРЕДЛОЖЕНИЯ В ТАТАРСКОМ И ФРАНЦУЗСКОМ ЯЗЫКАХ (ПОВЫШЕНИЕ КАЧЕСТВА ИНОЯЗЫЧНОГО ОБРАЗОВАНИЯ)
}

\section{EMOTIONAL EVALUATION SENTENCES IN TATAR AND FRENCH (IMPROVING THE QUALITY OF FOREIGN LANGUAGE EDUCATION)}

L. Ivanova

A. Gizatullina

Summary: At the present stage of the development of linguistic science, the study of languages in a comparative aspect has become particularly relevant. The purpose of this article is to identify the characteristics of emotional evaluative sentences in the context of a comparative analysis of the Tatar and French languages. Evaluation as one of the forms of manifestation of expressivity (in the context of the study of emotionally expressive sentences in these languages) is determined by the degree of involvement of the subject in the communication situation. Its specificity is determined by the physical and mental nature of man: it contributes to the formation of his thinking and activity, his attitude to other people and objects of reality. The semantic evaluation category is one of the universals in the language.

Keywords: emotionally expressive factor, emotionally expressive sentences, appraisal, good / bad, good / not good, important / not important, beautiful / not beautiful.

\author{
Иванова Лариса Филипповна \\ К.п.н., дочент, ГАОУ ДПО Институт развития \\ образования Республики Татарстан \\ metodiro@mail.ru \\ Гизатуллина Альбина Камилевна
}

К.филол.н., доцент, в.н.С., ГАОУ ДПО Институт развития образования Республики Татарстан

Albina27.3@mail.ru

Аннотация: На современном этапе развития лингвистической науки особую актуальность получили проблемы исследования языков в сопоставительном аспекте. Цель данной статьи состоит в выявлении особенностей эмоционально-оценочных предложений в контексте сопоставительного анализа татарского и французского языков. Оценочность как одна из форм проявления экспрессивности (в рамках исследования эмоционально-экспрессивных предложений в указанных языках), обусловлена степенью вовлеченности субъекта в ситуации общения. Ее специфика определяется физической и психической природой человека: она способствует формированию его мышления и деятельности, его отношения к другим людям и предметам действительности. Семантическая категория оценки представляет собой одну из универсалий в языке.

Ключевые слова: эмоционально-экспрессивный фактор, эмоционально-экспрессивные предложения, оценочность, хорошо / плохо, добро / не добро, важно / не важно, красиво / не красиво.

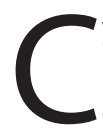

уществует целый комплекс средств, обеспечивающих выражение эмоционально-оценочного содержания, а также характеризующих языковую культуру в целом. Определяются эмоциональнооценочные предложения в качестве комплексных номинативных выражений, в которых раскрывается эмоциональное отношение говорящего к кому-либо или чему-либо. Данный способ передачи информации эмоционально-оценочного характера затрагивает не только лингвистические и экстралингвистические особенности высказывания, но и культурную и социальную специфику той или иной среды. Следует отметить, что практическая значимость данного исследования обусловлена тем, что его результаты могут использоваться при рассмотрении теоретических и практических проблем переводоведения, анализа языков в сопоставительном аспекте, типологии и методологии преподавания и непосредственно вопросов, связанных с лексикой, синтаксисом и стилистикой.
Эмоционально-экспрессивная функция языка обладает большой значимостью для процесса общения, для регулирования отношений между людьми. В настоящее время проводится ряд интересных исследований экспрессивных синтаксических единиц в рамках прагмалингвистической и психолингвистической теорий $[1 ; 3 ; 6 ; 11]$. Оценочность связана со сложной областью человеческих отношений. Этим определяется широкий диапазон семантических градаций значений «хорошо / плохо», «добро / не добро», «важно / не важно», «красиво / не красиво». Ф. Брюно отмечает, что «пожалуй, только при выражении оценочности яснее всего проявляется диспропорция между языковыми средствами и разнообразием аспектов эмоциональной оценки» [11, с. 557].

Категория оценочности представляет собой собственно человеческую категорию, заданную спецификой физической и психической природы человека, его бытием и чувствованием; она (категория) способствует фор- 
мированию его мышления, организации деятельности, отношения к другим людям и предметам действительности, восприятия искусства [1; 6]. Семантическую категорию оценки следует причислять к одной из значимых семантических универсалий в языке, поскольку она проникает во все его сферы. Так как буквально каждое слово в языке находится в тесной связи с той или иной степенью, с теми или иными видами оценочной коннотации или с прагмалингвистическим потенциалом, реализующимся во всевозможных языковых ситуациях, то категория оценки предстает как бы «разлитой» по всему словарному составу языка [1].

На сегодняшний момент, определяя оценочность как самостоятельную языковую категорию, ученые выражают различные точки зрения относительно природы этой категории, ее структуры, разграничения и функциональности видов оценки, классификации средств выражения. При этом и само определение категории оценочности недостаточно проработано. Вероятно, обусловлено это тем, что целый ряд вопросов практически не изучен: например, один из них (вопросов) связан с отношением данной категории и экспрессивности, эмоциональности, интенсивности.

С точки зрения лингвистических позиций под эмоциональной оценкой понимается фиксированная в семантике языковых единиц (положительного или отрицательного свойства) квалификация предмета, объекта действительности, исходя из признака «хорошо / плохо» с позиции субъекта речи. Языковая оценка является социально закрепленным, общественно устоявшимся отношением носителя языка и внеязыкового объекта, понимаемого в общем смысле как лицо, предмет, явление действительности и пр., которое выражается при помощи эксплицитных и имплицитных языковых средств. Данное отношение (субъекта к объекту с позиции противопоставления «положительное / отрицательное», т.е. «хорошо / плохо») представлено узуально или окказионально выражаемым семантическим свойством языкового явления, именуемого оценочностью [1; 9]. Мы разделяем это мнение и полагаем, что в основе оценочности лежит лингвофилософское понимание ценностного субъектно-объектного отношения в рамках аксиологического понятия «хорошо / плохо»:

\section{Хорошо / п^охо}

Башка малайлар кыяр сорап килгәндә: - һәй, тоз күзләр! Урлап ашавыгыз гына жстммәгән, оялмыйча сорарга да килгәнсез! [8, с. 362]. Когда приходят другие мальчишки огурцов попросить: - Ах, соленые глаза! Мало того, что вы своровав едите, не стыдясь еще и просить пришли! Кымшанма, сугыш чукмары! Аңгыра бәрән! [4, с. 456]. Не трясись, военщина! Болван! Молодец! [3, с. 65]. Молодец!
Temps de loups! marmonna la vielle tenant bon contre la tourmente comme si elle eut été taillée dans le granit [18, p. 36]. Волчье время! пробормотала дама в возрасте, держась против шторма, как будто она была вырезана из гранита. Pauvre homme!.. Pauvre homme! [15, p. 48]. Бедный человек!.. Бедный человек! Quelle bonne nouvelle! [19, p. 49]. Какая хорошая новость!

Анализируя данные примеры, можно установить, что ценностное понятие «хорошо / плохо» и в том, и другом языке выражено при помощи субстантивных предложений. Большое значение в вышеприведенных примерах имеют эмоционально-оценочные существительные и прилагательные. В целом ряде предложений двух сравниваемых языков употребляются междометия и восклицательные прилагательные нинди / quelle / какой (ая), которые интенсифицируют значение категории эмоциональной оценки. При этом важно отметить, что степень выраженности данной категории во французском языке определяется за счет артикля при существительном.

В то же время, оценочные значения в языке не могут ограничиваться лишь рамками логического понимания. Понятие «языковая оценка» предполагает охват довольно широкого диапазона языковых явлений аксиологии. Оценочность как одна из форм проявления экспрессивности (в рамках исследования эмоционально-экспрессивных предложений в указанных языках), обусловлена степенью вовлеченности субъекта в ситуации общения, т.е. пониманием того, насколько актуальна и значима для говорящего точка зрения и поведение собеседника. Она содержит в себе комплекс значений, отражающих отношение говорящего к сообщаемому по следующим признакам:

\section{$\triangle$ обро / не $\Delta$ обро}

Чүррәк баш! Өй хәтле өйне хәерче сәвиткә биреп, коры калыргамы? [5, с. 50]. Тряпичная голова! Такой дом бедным советам оставить и нищими остаться что-ли? Камилнен моңза йөрәге елый иде. Халык байлыгы бит! Шушы жүирне бакча итәргә күпме хезмат, күпме көч кергән [2, с. 42]. На это у Камиля сердче плакало. Это же богатство народа! Сколько труда, сколько сил ушло на то, чтобы эта земля превратилась в сад. Молодеи, йомры баш! [4, с. 78]. Молодеи, остроумный!

Je n'aime pas les vacances. - Petit menteur. Petit éffronté [17, p. 67]. Я не люблю каникулы. - Маленький обманщик. Маленький наглец. La belle Tina en personne! Bienvenue à mon ex-femme dans mon nouvel appartement! [19, р. 54]. Красавица Тина собственной персоной! Добро пожаловать в мою новую квартиру бывшей жены! Pauvre enfant! [19, p. 90]. Бедный ребенок! 


\section{Красиво / не красиво}

Жан азыгы! Кунеелләр нечкереп китmе сез жырлаганда [10, с. 43]. Пир души! На душе потеплело, когда вы пели. Авыл менә дигән безнен. Табигать почмагы прәме! Бер ж⿻ирдә дә юк бездегедай тугайлар. Урманы дисенме, суы. [7, с. 78]. Вот какая у нас деревня. Райский уголок прямо! Нет нигде такой нашей красоты. Лесов, скажешь, водоемов. Батыр! [4, с. 57]. Крепкий!

Ça va mieux? Et ce fiancé, où est-il? C'est là qu'il aurait dû se trouver. Une si charmante jeune femme! [12, p. 60]. Так лучше? И этот жених, где он? Там, где он должен находиться. Такая очаровательная молодая женщина! Oui, demain, il a une de ses réputées "cambrousse-paries". La si jolie vitrine! [13, p. 75]. И все-таки, я хочу сказать, что это «пародия на паритет». Очень красивая витрина! Quels vêtements! [14, p. 57]. Какая одежда!

\section{Важно / не важно}

Эх, бу кыз чаклар! Тиле чаклар! Г жсмернең яз чаклары! Язлар кабатлана, ә кыз чаклар кабатланмый... [10, с. 68].Эх, эта молодость! Глупый возраст! Возраст ранней весны! Весна повторяется, а молодость не повторяетСя...

Ah, әдәм баласының күңеле! Шарлотта аны аэропортка озатканда кочаклап-кочаклап елады [5, с. 59]. Ах, человеческая душа! Шарлотта, когда в аэропорт провожала, ее обнимая-обнимая плакала. Бик кирәкле эи! [4, с. 78]. Очень нужное дело!

Excellente idée! - reconnut Agoun'chich [14, p. 78]. Пpeкрасная идея! - признался Агуншиш. Pauvre fille! Que Dieu prenne soin d'elle! [16, p. 73]. Бедная девушка! Пусть Бог позаботится о ней! Ô dernier feu de l'année! [12, p. 72]. 0 , последний огонь года!

Итак, выявив основные особенности эмоциональнооценочных предложений в контексте сопоставительного анализа татарского и французского языков, можно сделать вывод о том, что данные предложения в большей степени используются в языке для того, чтобы выразить эмоциональную оценку. Такие ценностные понятия, как «добро / не добро», «красиво / не красиво», «важно / не важно», в вышеприведенных примерах на татарском и французском языках передаются при помощи эмоционально-оценочных существительных и прилагательных. Наиболее ярко категория оценочности проявляется как составной элемент распространенных и нераспространенных субстантивных предложений. Отметим, что ряд интенсификаторов (речь идет о вопросительных прилагательных, употребляемых во вторичной функции: нинди/quel; междометиях; частицах и т.д.), обеспечивает усиление значений эмоциональной оценки и переводят данные предложения из категории оценочных в категорию эмоционально-экспрессивных. Во всех вышепредставленных определениях оценка характеризуется положительным или отрицательным отношением говорящего субъекта, выражение которого (отношения) закрепляется за счет языковых средств. Таким образом, оценочность - это категория, представленная при помощи языковых единиц и, в связи с этим, являющаяся фактом языка, областью функционирования которого служит речь.

Эмоциональная оценка, будучи языковым явлением, реализуется в системе языка не изолированно, она обладает определенными корреляциями с соотносительными компонентами данной системы, которые и позволяют выразить ее коммуникативный функционал. В этом смысле оценочность, главным образом, обусловлена связью с модальностью (прежде всего, субъективной модальностью, экспрессивностью и эмотивностью), способствующей при помощи определенных средств языка выражать субъективное отношение говорящего по отношению к предметам и явлениям объективной действительности.

На примерах эмоционально-оценочных предложений в татарском и французском языках мы убедились, что эмоциональная оценка многогранна и охватывает различные сферы жизнедеятельности двух народов, языки которых представлены в данной статье. Надеемся, что анализ возможных коммуникативных ситуаций, эмоционально-оценочных предложений покажет красоту, эмотивность и живость этих двух сопоставляемых языков.

\section{ЛИТЕРАТУРА}

1. Арутюнова Н.Д. Аксиология в механизмах жизни и языка // Проблемы структурной лингвистики. - М.: «Наука», 1982. - С. 5-23.

2. Бәширов Г. Әсәрләр: 4 т. - III т. - Казан: Тат. кит. нәшр., 1983. - 4226.

3. Гизатуллина А.К. Изобразительность как смысловая составляющая экспрессивности в эмоционально-экспрессивных предложениях в татарском и французском языках // Филологические науки. Вопросы теории и практики. - Тамбов: «Грамота», 2014. - Ч. 1.; № 3. - С. 64-67.

4. Гыйләжев А. Повестьлар // Әсәрләр: 4 т. - ІІ т. - Казан: Тат. кит. нәшр., 1994. - 5046.

5. Гыйматдинова Н. Кыргый: Повестьлар. - Казан: Тат. кит. нәшр., 1996. - 1426.

6. Коноваленко Л.И. Семантико-синтаксические средства выражения оценочной модальности в русском и английском языках: автореф. дисс. ... канд. филол. наук. - Краснодар, 1997. - 23 с. 
7. Минский Г. Яшенле яңгыр. - Казан: Тат. кит. нәшр., 1976. - 367 б.

8. Нуруллин В. Күпер чыкканда: Повестьлар. - Казан: Тат. кит. нәшр., 1985. - 4646.

9. Почепцов Г.Г. Прагматический аспект изучения предложения // ИЯШ. - М., 1975. - № 6. - С. 15-26.

10. Рафиков С. Авыл иртәсе: Роман. - Казан: Тат. кит. нәшр., 1966. - 3596.

11. Brunot F. La pensée et la langue (méthode, principes et plan d'une théorie nouvelle du langage appliquée au français). - Paris: Masson et C(il), 1936. - 982 p.

12. Gordon A. Rue Pouchkine. - Paris: Albin Michel, 1995. - 357 p.

13. Coatmeur J.-F. La porte de l'enfer. - Paris: Albin Michel, 1997. - 337 p.

14. Khaïr E. Légende et vie d'Agoun'chich. - Paris: Seuil, 1984. - 159 p.

15. Lapouge G. Lincendie de Copenhague. - Paris: Albin Michel, 1995. - 411 p.

16. Jelloun T. Jour de silence à Tanger. - Paris: Seuil, 1990. - 123 p.

17. Juliet C. L'année de l'éveil. - Paris: P.O.L., 1989. - 236 p.

18. Fernandez D. L'école du sud. - Paris: Bernard Grosset, 1991. - 438 p.

19. Weyergans F. Franz et François. - Paris: Bernard Grosset, 1997. - 414 p.

(c) Иванова Лариса Филипповна (metodiro@mail.ru), Гизатуллина Альбина Камилевна (Albina27.3@mail.ru ).

Журнал «Современная наука: актуальные проблемы теории и практики»

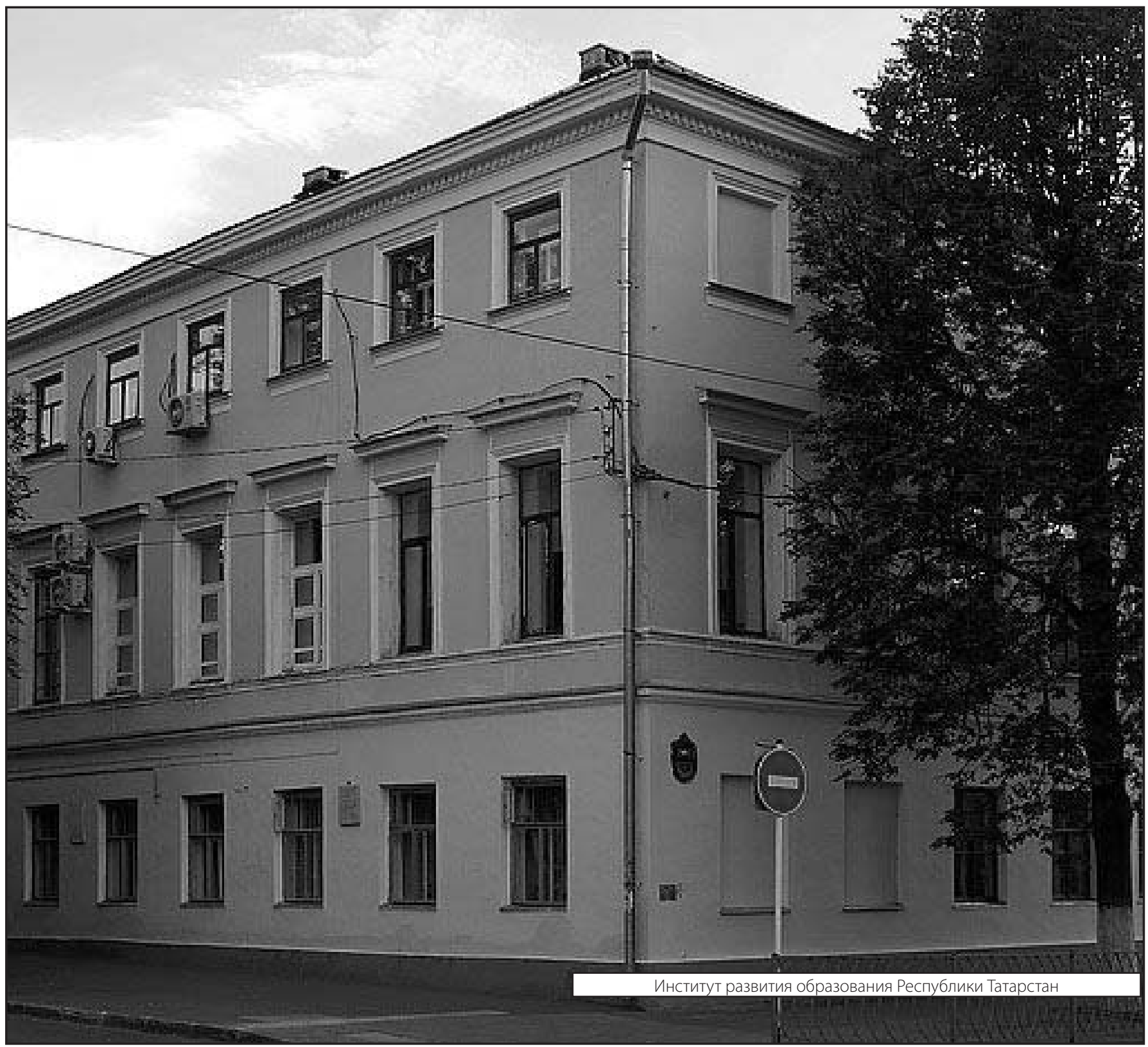

